\title{
The identity of twelve scincid generic names proposed by Cope in 1892 (Squamata: Scincidae)
}

\author{
GLENN M. SHEA \\ Sydney School of Veterinary Science B01, University of Sydney, NSW 2006, Australia \\ Australian Museum Research Institute, Australian Museum, 1 William St, Sydney, NSW 2010, Australia \\ झ"glenn.shea@sydney.edu.au; @ ittps://orcid.org/0000-0002-0052-4205
}

\begin{abstract}
The twelve generic names proposed by Cope in 1892, which were created without included species, are linked to existing taxa by recognition that Cope's key is a simple modification of the previous skink generic key by Boulenger in 1887 , splitting existing genera of Boulenger in accordance with the morphology of the species included in those genera. This insight allows for Cope's generic names Dicloniscus, Dimeropus, Haploscincus, Ollochirus, Oncopus, Podoclonium and Tridentulus to be linked to single species in Boulenger's treatment, and thus those species are identified as the types of those genera, resulting in synonymy of Dicloniscus with Chalcides, Dimeropus with Larutia, Haploscincus with Lipinia, Podoclonium with Scelotes, and Ollochirus, Oncopus and Tridentulus with Lerista. Furcillus, Mesomycterus, Monophorus and Monophyaspis are associated with multiple species in Boulenger's classification, and type species are designated that minimize change to existing nomenclature but facilitate application of the names to otherwise unnamed lineages in case future divisions are considered warranted. Furcillus becomes a synonym of Lerista, Mesomycterus becomes a synonym of Brachyseps, Monophorus becomes a synonym of Phoboscincus and Monophyaspis becomes a synonym of Trachylepis. Lepidothyrus, for which a type species was previously identified, is a synonym of Mochlus. Reversal of precedence is invoked to avoid the need for use of the senior synonyms Dimeropus and Monophorus over the frequently used Larutia and Phoboscincus, however, Mesomycterus is a senior synonym of Brachyseps, and replaces that recently created name.
\end{abstract}

Key words: Dicloniscus, Dimeropus, Furcillus, Haploscincus, Lepidothyrus, Mesomycterus, Monophorus, Monophyaspis, Oncopus, Ollochirus, Podoclonium, Tridentulus

Edward Drinker Cope (b. 28 July 1840, d. 12 April 1897) was a major figure in $19^{\text {th }}$ century reptile biology. Best known in popular culture for his rivalry with Othniel Charles Marsh in describing dinosaurs and other Mesozoic megafauna (Davidson 1997), he also contributed many papers on Recent reptiles, culminating in his posthumous monograph, The Crocodilians, Lizards, and Snakes of North America (Cope 1900). In particular, his anatomical studies strongly influenced the classification of lizards for many years, being the basis for the classification used by Boulenger (1885a,b, 1887), which would become the major reference work on the lizards for nearly half a century after.

In a work exploring limb reduction in lizards, Cope (1892) provided a key to the skinks, concentrating on those with limb reduction. In this, he first proposed a number of new generic names: Dicloniscus, Dimeropus, Furcillus, Haploscincus, Lepidothyrus, Mesomycterus, Monophorus, Monophyaspis, Oncopus, Ollochirus, Podoclonium and Tridentulus. This key and the names therein were republished in Cope (1900) and were listed by Dunn \& Dunn (1940), who did not consider the names valid as they were not originally published with any included species. However, under the current Code of Zoological Nomenclature generic names proposed without included species are validly published and available (Article 11.4.1), and their application awaits nomination of type species (Article 67.2.2).

It has not been previously noted that Cope's key is based on that of Boulenger (1887) for skinks, using the same major characters in the same order and hierarchy. This, together with the stepped morphological characters used in both keys, allows for identification of the species by comparison of the species listed by Boulenger with those character states, within those Boulengerian genera and subgenera that were divided by Cope. Cope's additional 
divisions within the framework provided by Boulenger were largely based on number of digits (recognizing generic boundaries for every combination of digits, where Boulenger's genera and subgenera had included taxa with varying combinations of digits on front and hind limbs) and the fusion of the frontoparietal scales.

In this paper, I use a comparison of Cope's and Boulenger's keys, together with Boulenger's species taxonomy, to determine the species that comprised Cope's new genera, and select type species for those genera to allow assignment of the generic names in a modern taxonomy. The validity of this approach is validated by the one instance where Cope (1900) subsequently mentioned a species in one of his new genera, Lepidothyrus. This is the only one of Cope's 12 generic names that has been subsequently used, by Wagner et al. (2009), and the listed species, Tiliqua fernandi Burton 1836, fits the diagnosis provided by Cope, and its placement in Boulenger's classification matches the placement of the genus in Cope's classification.

Where there are differences in numbering/labelling of the steps in the two keys, I provide Cope's character identifiers first, then Boulenger's in square brackets. Cope's key provided authorships for genera, but these are lacking in Boulenger's key (Boulenger instead provided authorships in the generic accounts). Where Cope abbreviates author names, I give the full name for the first use of the abbreviation, again in square brackets.

Both Boulenger's and Cope's keys begin with the following characters and genera, constituting subdivisions within the first character pair of the position of the nostril, a set of character states that largely distinguishes skinks of the subfamilies Lygosominae and Scincinae in modern day taxonomy.

I. Nostril pierced in the nasal, or between the nasal and supra- or post-nasal or first upper labial, not touching the rostral.

A. Palatine bones separated on the median line of the palate; no supranasal shields.

No azygos occipital shield; Egernia Gray.

An azygos occipital shield in contact with the interparietal; tail prehensile; Corucia Gray.

AA. (B.) Palatine bones in contact on the median line of the palate.

1. Tympanum, if distinct, more or less deeply sunk.

a. Pterygoid bones separated on the median line of the palate, the palatal notch extending anteriorly to an imaginary line connecting the centre of the eyes.

$\alpha$. No supranasals

Lateral teeth with obtuse or spheroidal crowns; an azygos occipital in contact with the interparietal; subdigital lamellae divided; Trachysaurus Gray.

Lateral teeth with obtuse or spheroidal crowns; subdigital lamellae undivided;

Tiliqua Gray.

An enormous crushing tooth on each side of each jaw; Hemisphaeriodon Ptrs. [Peters]

$\beta$. Supranasals present.

Lateral teeth with compressed, denticulated crowns; a series of suborbital shields;

Macroscincus Bocage.

Lateral teeth conical; two frontoparietals; Mabuia Fitz. [Fitzinger]

Lateral teeth conical; one frontoparietal; Monophyaspis Cope.

Boulenger does not list the last line, but instead gives the line leading to Mabuia as "Lateral teeth conical; Mabuia". Hence, Monophyaspis represents a division of Boulenger's Mabuia on the basis of frontoparietals fused into a single scale, leaving those species with paired frontoparietals in Mabuia.

The keys then continue:

$b$. Pterygoids in contact (at least quite anteriorly) mesially, the palatal notch not extending anteriorly to between the centre of the eyes.

* Eyelids moveable; digits with non-retractile claws.

In Boulenger's key, this last line leads to the genus Lygosoma, a large genus for which a separate key recognises 11 subgenera. The diagnostic characters for these subgenera extensively use combinations of three characters: supranasal scales present or absent, lower eyelid scaly or with a transparent window, and ear opening present, or covered by scales. The same three characters, with the addition of digital formulae and fusion of frontoparietals, 
are extensively used in the next section of Cope's key, which is not paralleled by keys in Boulenger, but clearly represents a division of Boulenger's Lygosoma:

* Eyelids moveable; digits with non-retractile claws.

$\dagger$ Supranasal plates present (tympanum not concealed)

$\$$ Lower eyelid with a transparent disk.

$\S$ Frontoparietal single.

Digits 5-5; Emoa Gray.

Digits 5-4; Hagria Gray.

Digits 4-4; Chiamela Gray.

$\S \S$ Two frontoparietals.

Digits 5-5; Riopa Gray.

Digits 2-3; Eumecia Bocage.

t+ Lower eyelid scaly

$\S$ Frontoparietal single.

Digits 5-5; Monophorus Cope.

$\S \S$ Two frontoparietals.

Digits 5-5; Lepidothyris Cope.

The combination of supranasal scales present and ear not concealed corresponds to Boulenger's subgenera Otosaurus, Emoa, most Riopa and some Keneuxia within his Lygosoma. With Emoa already recognised by Cope, the rest of the genera he recognises (Hagria, Chiamela, Riopa, Eumecia, Monophorus and Lepidothyris) and their diagnostic combinations, fit the species in Boulenger's Riopa, a name under which Boulenger subsumed the type species of Hagria, Chiamela and Eumecia. The key to Boulenger's subgenus Riopa, which consisted of 21 species, makes a primary division into species that are pentadactyle, and those that have reduced numbers of digits (with the three permutations 5-4, 4-4 and 2-3 being the same possible permutations for this group as Cope), and then among the pentadactyle species, into those with single frontoparietal vs two frontoparietals, and then those with windowed lower eyelid as against a scaly lower eyelid, characters again used by Cope though in different order. The few species in Boulenger's Otosaurus and those of his Keneuxia with supranasal scales would fall into Cope's Lepidothyris, by definition having an unscaled tympanum, supranasal scales, a scaly lower eyelid, unfused frontoparietals and pentadactyle limbs, along with a few species of Boulenger's Riopa (those in his subset $(\mathrm{VI})(\mathrm{A})(2)(b)(\alpha)$ ). This latter group includes Riopa fernandi, which Cope (1900) later listed as belonging to Lepidothyris.

The next part of Cope's key, still with reference to the content of Boulenger's Lygosoma, reads:

$\dagger$ Supranasal plates wanting.

\$ Lower eyelid with a transparent disc.

// Tympanum not concealed.

$\S$ Frontoparietal plate single.

Digits 5-5; Mocoa Gray.

Digits 4-5; Heteropus D. \& B. [Duméril \& Bibron]

Digits 1-2; Brachystopus D. \& B.

Digits 1-2; Oncopus Cope.

Digits 0-2; Ollochirus Cope.

Digits 0-1; Soridia Gray.

$\S \S$ Frontoparietal plate double.

Digits 5-5; Liolepisma D. \& B.

Digits 3-3; Tridentulus Cope.

Digits 1-2; Furcillus Cope.

// // Tympanic meatus closed.

$\S$ Frontoparietal single.

Digits 5-5; Haploscincus Cope.

$\S \S$ Frontoparietals distinct. 
Digits 4-4; Tetradactylus Merr. [Merrem]

Digits 3-3; Hemiergis Wagl. [Wagler]

Digits 2-2; Chelomeles D. \& B.

Within this section, the first division (supranasal plates wanting) fits Boulenger's subgenera Hemiergis, Hinulia, Homolepida, Liolepisma [a misspelling of Leiolopisma Duméril \& Bibron], Rhodona and Siaphos, along with one species of Keneuxia. Of these, Hemiergis, Liolepisma, Rhodona and some Siaphos fit the subcategory lower eyelid with a transparent disk. The next criterion, tympanum not concealed, reduces this list to Liolepisma and Rhodona. Cope's defining characters for his group of genera split both of Boulenger's Liolepisma and Rhodona, both of which show variation in digital formula and fusion of frontoparietals. Cope's genera Heteropus, Mocoa and Liolepisma are names subsumed under Boulenger's Liolepisma and hence represent Cope's division of that subgenus. This means that Cope's Brachystopus, Furcillus, Oncopus, Ollochira, Soridia and Tridentulus fit Boulenger's Rhodona. The type species of Brachystopus and Soridia are within Boulenger's Rhodona, and the combinations of digital formulae used by Cope for the six genera match exactly the nine species included by Boulenger in his subgenus. Therefore, the new generic names Furcillus, Ollochira, Oncopus and Tridentulus represent divisions of Rhodona.

Cope's diagnosis of lower eyelid with a transparent disc, tympanic meatus closed and frontoparietal single (Haploscincus), fits only a single Boulengerian species, one which he included in his subgenus Siaphos (the only species of Siaphos identified as having a windowed eyelid).

The group of three genera with the tympanic meatus closed and paired frontoparietals uniquely matches Boulenger's subgenus Hemiergis, and Cope's three genera within this group exactly match the three permutations of digital formulae in that lineage, for which the generic names Tetradactylus and Chelomeles already existed.

The next part of Cope's key covers the remaining parts of Boulenger's Lygosoma:

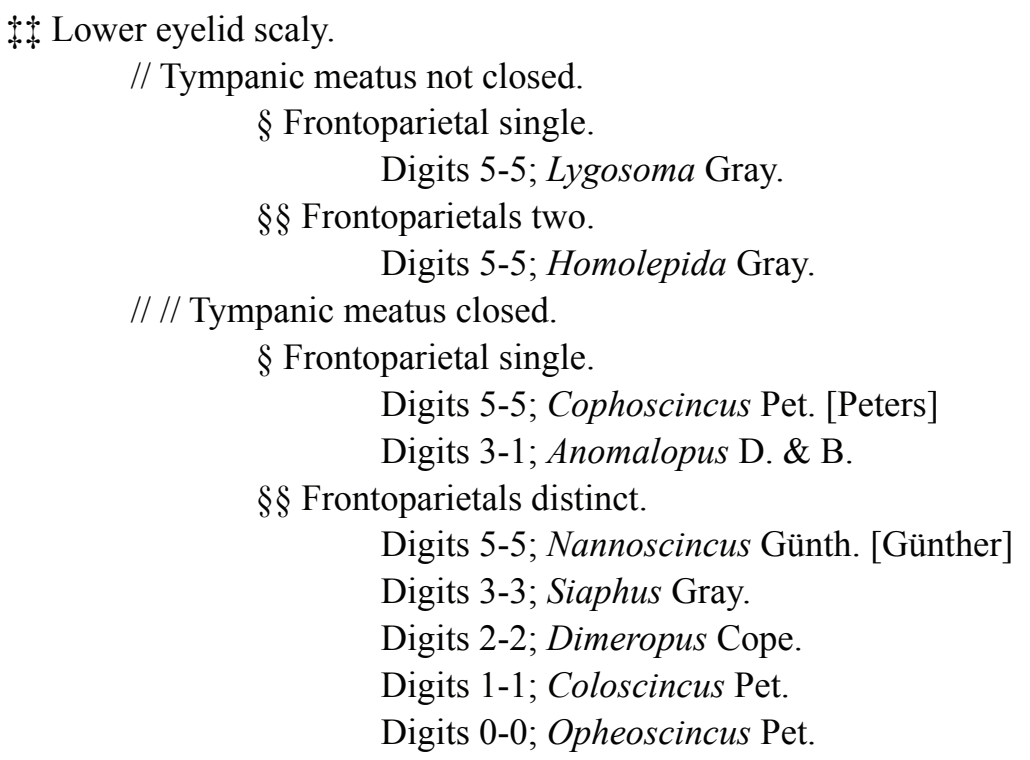

This section of Cope's key covers Boulenger's subgenera Homolepida, Lygosoma, and the remainder of Siaphos (which Cope misspells as Siaphus, with both Boulenger and Cope misspelling Gray's (1831) original Saiphos), which again show combinations of fusion of frontoparietal scales and scaly ear within those subgenera. Cope's Homolepida corresponds almost completely with that subgenus of Boulenger, with only one of Boulenger's species having fused frontoparietals. Cope's genus Lygosoma agrees with the first division of Boulenger's subgenus Lygosoma (those with a distinct ear) while the other five species of Boulenger's subgenus, with a scaly ear, correspond to Cope's Anomalopus, Dimeropus, Coloscincus and Opheoscincus (a misspelling of Ophioscincus Peters 1874), with the modern day concepts of Anomalopus and Ophioscincus, the latter incorporating the generic name Coloscincus, and the digital formulae 3-1, 2-2, 1-1 and 0-0 corresponding exactly to the permutations in the species recognised by Boulenger in his subgenus (although in defining Anomalopus as having fused frontoparietals, Cope may have been confused with Boulenger's account of the only species of Anomalopus then known, A. verreauxii Duméril \& Duméril 1851, which confuses frontoparietals with prefrontals). The six species of Boulenger's Siaphos can be 
allocated exactly to Cope's definitions of Cophoscincus and Nannoscincus (those which are pentadactyle and have either fused or paired frontoparietals), and Siaphus (the one tridactyle species), and the existing generic names used by Cope have type species that were part of Boulenger's subgenus Siaphos.

The remainder of Cope's key, with Boulenger's Lygosoma now dealt with, returns to matching Boulenger's generic key, beginning with the ablepharine genera. This next section of Cope's key is:

** eyelids immovable, transparent, covering the eye.

$\dagger$ Supranasals present. Two frontoparietals; ear exposed.

Digits 5-5; Panaspis Cope.

$\dagger \dagger$ No supranasals.

// Two frontoparietals (ear not closed).

Digits 5-5; Ablepharus Fitz.

Digits 4-4; Miculia Gray.

Digits 3-3; Phaneropis Fischer.

Digits 2-3; Lerista Gray.

// // One frontoparietal.

$\S$ Ear exposed.

Digits 5-5; Cryptoblepharus Wiegm. [Wiegmann]

Digits 4-5; Menetia Gray.

Digits 4-4; Blepharactisis Hallow. [Hallowell]

$\S \S$ Ear concealed.

Digits 5-5; Blepharosteres Stolicz. [Stoliczka]

*** Eyelids moveable; claws retractile into a sheath.

Digits 4-5; Ristella Gray.

2. Tympanum exposed and superficial.

Head normal. Tropidophorus D. \& B.

Head a bony casque, well separated from the neck; Tribolonotus D. \& B.

The only deviation of this part of Cope's key from that of Boulenger is to divide Boulenger's Ablepharus ("eyelid immovable, transparent, covering the eye") into multiple genera, including Panaspis Cope, a genus previously defined by him (Cope 1869), again on the basis of combinations of digital formulae, ear exposure and frontoparietal fusion, and with the permutations of digital formula matching exactly those combinations present in Boulenger's Ablepharus.

The final section of Cope's key deals with what are considered at the present time to constitute the subfamily Scincinae.

AAA. [C]. Palatine bones separated on the median line; supranasal shields present

Nostril pierced in the nasal; pterygoid bones toothed; limbs pentadactyle, the digits not denticulated laterally; Eumeces Wiegm.

Nostril pierced in a very small nasal, between the rostral, the first labial, the supranasal, and sometimes a postnasal; palate toothless; digits 5-5; limbs short; Senira Gray.

Like Senira, but limbs rudimentary, undivided; Brachymeles D. \& B.

Nostril pierced between an upper and a lower nasal; limbs pentadactyle, the digits denticulated laterally; Scincus Laur.

Nostril pierced between the nasal and supranasal; digits 4-3; Zygnopsis Blfd. [Blandford]

Like Zygnopsis, but digits 3-3; Sphenoscincus Pet.

Like Zygnopsis, but digits 3-2; Hemipodium Steind. [Steindachner]

Like Zygnopsis, but limbs absent; Opheomorus D. \& B.

II. Nostril pierced in the posterior border of the rostral, or between a nasal or a labial and the rostral.

A. Palatine bones in contact on the median line.

Nostril pierced between the rostral and a very small nasal, which may be reduced to a narrow ring. 
Digits 5-5; frontoparietal distinct; Thyrus Gray.

Digits 5-5; no frontoparietals or prefrontals; Amphiglossus D. \& B.

Digits 3-3; Sepomorphus Pet.

No fore limbs; hind limbs didactyle; Scelotes Fitz.

No fore limbs; hind limbs undivided; Podoclonium Cope.

No limbs externally; Herpetosaura Pet.

AA. Palatine bones separated on the median line.

1. Supranasals present; first upper labial not touching the nostril.

* Nostril pierced between the rostral and a very small nasal in an emargination of the former shield.

a. Labial border rounded.

Digits 5-5; Gongylus Wagl. [Wagler]

Digits 4-4; Gongyloseps Boettg. [Boettger]

Digits 3-4; Allodactylus Lataste.

Digits 2-4; Anisoterma Dum.

Digits 2-3; Heteromeles D. \& B.

Digits 1-1 (limbs undivided); Dicloniscus Cope.

aa. Labial border projecting; acute.

Digits 5-5 - 4-4; Sphaenops Wagl.

** Nostril pierced between the rostral and a very small nasal, which is situated between the former shield and the first labial.

No limbs; Herpetoseps Blgr. [Boulenger]

2. Supranasals present; first upper labial entering the nostril.

* Nostril pierced between the rostral, the supranasal, the postnasal, and the first labial; no frontoparietals.

Digits 5-5; Mesomycterus Cope.

Digits 4-4; Rhinoscincus Peters.

Digits 3-3; Sepsina Bocage.

No fore limbs; hind limbs undivided; Dumerilia Bocage.

** Nostril pierced between the rostral, the supranasal, and the first labial; frontoparietals present.

Limbs absent; Sepophis Bedd. [Beddome]

3. No supranasals; nostril entirely in the rostral.

Digits 4-4; Chalcidoseps Blgr.

This final segment corresponds exactly with Boulenger's key, except for expansion at three points, and an apparent lapsus in omitting Boulenger's Melanoseps after Dumerilia (restored in the version of Cope 1900). Senira is distinguished from Brachymeles (with the addition of a new line for the character distinguishing Brachymeles from Senira). The group of genera Zygnopsis, Sphenoscincus, Hemipodium and Opheomorus [= Ophiomorus Duméril \& Bibron 1839] represent divisions of Boulenger's Ophiomorus, which is diagnosed in the latter key by the statement "nostril pierced between the nasal and the supranasal; limbs rudimentary or absent". The group of genera Thyrus, Amphiglossus, Sepomorphus, Scelotes, Podoclonium and Herpetosaura similarly represent divisions of Boulenger's Scelotes, with the latter reached at the statement "nostril pierced between the rostral and a very small nasal, which may be reduced to a narrow ring", and the type species of Thyrus, Amphiglossus, Sepomorphus and Herpetosaura being incorporated in Boulenger's Scelotes. The group of genera Gongylus, Gongyloseps, Allodactylus, Anisoterma, Chalcides, Heteromeles, Dicloniscus and Sphaenops represent divisions of Boulenger's Chalcides, with the latter reached at the statement "nostril pierced between the rostral and a very small nasal, in an emargination of the former shield", and the type species of Gongylus, Gongyloseps, Allodactylus, Anisoterma and Heteromeles being incorporated in his Chalcides. The group of genera Mesomycterus, Rhinoscincus, Sepsina and Dumerilia represent divisions of Boulenger's Sepsina, with the latter reached at the statement "nostril pierced between the rostral, the supranasal, the postnasal, and the first labial; no frontoparietals", and the type species of Rhinoscincus and Dumerilia being incorporated in Boulenger's Sepsina. Hence, Cope's Podoclonium represents the sole species of Boulenger's Scelotes with a digital formula 0-1, Dicloniscus represents the sole species of Boulenger's Chalcides with digital formula 1-1, and Mesomycterus represents the five species of Boulenger's Sepsina which are pentadactyle. 


\section{Selection of type species for Cope's generic names}

Several of the new generic names represent only single species in Boulenger's (1887) catalogue, and hence the selection of type species is simple.

The type species of Dicloniscus (misspelt as Dicloniseus by Cope 1900) is the single species of Boulenger's Chalcides with a digital formula of 1-1: Chalcides guentheri Boulenger 1887. The type species of Dimeropus is the only species in Boulenger's Lygosoma (Lygosoma) with paired frontoparietals, scaly ear and digital formula 2-2: Chelomeles sumatrensis Bleeker 1860. The type species of Haploscincus is the sole species of Boulenger's Siaphos reported as having a windowed lower eyelid, scaled ear, single frontoparietal, and 5-5 digits: Cophoscincus infralineolatus Günther 1873. The type species of Ollochirus is the single species of Boulenger's Rhodona with fused frontoparietals and digital formula of 0-2: Rhodona bipes Fischer 1882. The type species of Oncopus is the only species of Boulenger's Rhodona with fused frontoparietals and 1-1 digits: Soridia miopus Günther 1867. The type species of Podoclonium is the single species of Boulenger's Scelotes with a digital formula of 0-1: Scelotes guentheri Boulenger 1887.

The type species of Tridentulus is slightly less clear, but it must be a species of Rhodona with digital formula 3/3. There is only one species of Boulenger's Rhodona with that digital formula, Rhodona fragilis Günther, 1876. However, Cope diagnoses his genus Tridentulus as also having paired frontoparietals, while $R$. fragilis has fused frontoparietals. However, in that there is no tridactyle Rhodona with unfused frontoparietals in Boulenger's classification, and Cope does not have a category for a tridactyle species among those genera with fused frontoparietals, it is presumed that Cope erred in including the character state paired frontoparietals for his Tridentulus, and designate $R$. fragilis as the type species of Tridentulus.

While it is now clear that Cope's concept of Lepidothyrus included several species from Boulenger's Lygosoma, the inclusion of only fernandi in combination with the generic name by Cope (1900) qualifies as a definition of type species under the Code (Article 67.2.2).

For the remaining four Cope genera, more than one species fits the generic diagnosis, and a choice is required to be made.

Furcillus represents the species of Boulenger's Rhodona with paired frontoparietals and digital formula 1-2. The two species with this combination (Boulenger's consecutive Lygosoma species 146 and 147) are Rhodona gerrardii Gray 1864 and Rhodona punctatovittata Günther 1867. Of the two, Boulenger reported variation in the digital formula of the former (both 1-2 and 2-2), but no variation in the latter. Hence, I designate Rhodona punctatovittata Günther 1867 as the type species of Furcillus, the species best fitting his diagnosis at the time of description.

Monophorus represent the species of Boulenger's Riopa with scaly lower eyelid, single frontoparietal and pentadactyle limbs. Boulenger lists two species fitting this diagnosis: Eumeces microlepis Duméril \& Bibron 1839 and Eumeces garnieri Bavay 1869 (Boulenger's consecutive Lygosoma species 100 and 101), with a third species, Eumeces bocourti Brocchi 1876, tentatively considered a synonym of E. garnieri. The three species are currently distributed across two genera described subsequent to Cope, and hence the choice of type species will determine which generic name Monophorus becomes a senior synonym of, either Tachygyia Mittleman 1952 (type species Eumeces microlepis) or Phoboscincus Greer 1974 (type species Eumeces bocourti, but with E. garnieri also referred to that genus at the time it was created). I select E. garnieri Bavay 1869 as the type species of Monophorus. This will allow that name to be used if garnieri is ever considered to not be congeneric with bocourti, avoiding the need for creation of a new generic name for garnieri.

Monophyaspis represents those species of Boulenger's Mabuia (now divided into multiple genera within a tribe Mabuyiini, the tribe representing the former Mabuia/Mabuya) with a single frontoparietal. Boulenger lists six species in his Mabuia with single frontoparietals: Euprepes delalandii Duméril \& Bibron 1839, Mabuia vaillantii Boulenger 1887, Emoea frenata Cope 1862, Mabuia gravenhorstii Duméril \& Bibron 1839, Euprepes bayonii Bocage 1872 and Euprepes isselii Peters 1871. Of these, E. delalandii and M. vaillantii are now in the genus Chioninia Gray 1845 (type species E. delalandii), E. frenata is the type species of the monotypic genus Notomabuya Hedges \& Conn 2012, and M. gravenhorstii, E. bayonii and E. isselii are currently in the genus Trachylepis Fitzinger 1843 (type species Euprepes savignyi Duméril \& Bibron, 1839; = T. quinquetaeniatus Lichtenstein 1823; Bauer 2003), with $E$. isselii considered a junior synonym of $T$. varia (Peters 1867). Utility of the name (as a potential generic name should other genera be split) while avoiding supplanting the existing name Notomabuya would be best served by designating as type one of the species currently in the speciose genus Trachylepis. A recent genetic 
phylogeny for Trachylepis by Weinell et al. (2021) places these three species in three different sublineages of the genus, two of which represent the major lineage for which the name Oxytropus Fitzinger 1843 is already available. Hence, I designate Mabuia gravenhorstii Duméril \& Bibron 1839 as the type species of Monophyaspis, providing an available generic name should the Malagasy mabuyins be considered to warrant separate status in the future.

Mesomycterus represents the pentadactyle species of Boulenger's Sepsina: Gongylus gastrostictus O'Shaugnessy 1879, Gongylus splendidus Grandidier 1872, Gongylus macrocercus Günther 1882, Gongylus melanurus Günther 1877, and Gongylus johannae Günther 1880. These species are currently spread over two genera, the recently described (Erens et al. 2017) Flexiseps (johannae and melanurus, with melanurus the type of Flexiseps) and Brachyseps (gastrostictus, macrocercus and splendidus, with macrocercus the type of Brachyseps, and gastrostictus possibly synonymous with macrocercus). Choice of a type species will therefore supplant one of these two genera, both too recently described to invoke the Code's reversal of precedence articles for preservation. I select Gongylus splendidus Grandidier 1872 as the type of Mesomycterus. This species was only tentatively included in Brachyseps by Erens et al. (2017), with its genetic placement being outside both Brachyseps and Flexiseps, but with low support. Hence, it may prove to represent a lineage distinct from both genera with further work.

\section{Synonymy of the Cope genera}

With the identification of type species, it is now possible to assign these generic names in a modern taxonomic framework.

The genera Furcillus, Ollochirus, Oncopus and Tridentulus are junior subjective synonyms of Lerista Bell 1833. Dicloniscus is a junior subjective synonym of Chalcides Laurenti 1768. Monophyaspis becomes a junior subjective synonym of Trachylepis Fitzinger 1843. Podoclonium is a junior subjective synonym of Scelotes Fitzinger 1826. Haploscincus is a junior subjective synonym of Lipinia Gray 1845 on current taxonomy. However, Lipinia has recently been shown to be polyphyletic (Pyron et al. 2013; Rodriguez et al. 2018). The earliest generic name for the lineage to which the type species of Haploscincus belongs is Cophoscincus Peters 1867 (Shea 2017), and it remains a junior synonym in that genus. Lepidothyrus was resurrected by Wagner et al. (2009) for a genus of West African lygosomines, but that genus was recently synonymized (Freitas et al. 2019) with Mochlus Günther 1864.

The remaining three genera are senior synonyms of existing names, although it is possible to avoid the need to supplant the names in current use for two of these. The International Code of Zoological Nomenclature requires a senior synonym to not be used when two conditions are met:

Article 23.9.1.1. the senior synonym or homonym has not been used as a valid name after 1899, and

Article 23.9.1.2. the junior synonym or homonym has been used for a particular taxon, as its presumed valid name, in at least 25 works, published by at least 10 authors in the immediately preceding 50 years and encompassing a span of not less than 10 years.

Other than Lepidothyrus, which was validated by being used in combination with a species by Cope (1900) and then resurrected by Wagner et al. (2009), the names proposed by Cope (1892) have appeared only three times. Cope (1900) reprinted the key he created in 1892. Although this paper appeared one year after the cutoff date for Article 23.9.1.1, it was published posthumously, appearing three years after Cope's death in 1897, and the names only appear in the key, without any indication of species, or application of the names other than Lepidothyrus. Hence, I do not consider these names to have been used in that publication, the key being merely replicated from the earlier pre-1900 paper. Dunn \& Dunn (1940) listed them in creating a catalogue of the generic names created by Cope, but did not treat the names as available. Neave (1939-1940) lists them in his Nomenclator Zoologicus, but names in nomenclators are specifically excluded from consideration as usage under the Code (Article 23.9.6).

Monophorus is a senior subjective synonym of Phoboscincus Greer 1974. Phoboscincus has been used as the name for a genus consisting of bocourtii and garnieri by the following 25 papers by more than 10 authors in the past 50 years, and over a period of not less than 10 years: Sadlier (1987); Bauer \& Vindum (1990); Bauer \& Sadlier (1993, 2000); Adler et al. (1995); Sadlier \& Bauer (1997a,b); Greer (2001); Ineich (2006, 2009); Greer \& Chong (2007); Smith et al. (2007); Meiri (2008); Mittermeier et al. (2009); Beolens et al. (2011); Caut et al. (2013); Geneva et al. (2013); Hedges (2014); Ineich et al. (2014); Daza et al. (2015); Langner \& Sound (2016); Thibault et al. (2017); Sadlier et al. (2019); Rodda (2020); O’Shea (2021). 
Dimeropus is a senior subjective synonym of Larutia Böhme 1981. Larutia has been used as the valid name for that genus by the following 25 papers by more than 10 authors in the past 50 years, over a period of not less than 10 years: Lang \& Böhme (1990); Greer (1997, 2002); Manthey \& Grossmann (1997); Chan-ard et al. (1999, 2011a,b); Das \& Lim (2001); J. Grismer et al. (2003, 2004); Greer et al. (2006); L. Grismer et al. (2010, 2011); Teynié et al. (2010); L. Grismer (2011); Norhayati et al. (2011); Hedges (2014); Goldberg et al. (2015, 2019a,b); Quah et al. (2018); Chan et al. (2019); L. Grismer \& Quah (2019); Ibuki et al. (2019); Chan \& L. Grismer (2021).

Hence, in both cases, I invoke Article 23.9 to reverse the precedence of the names, so that Monophorus may not be used while it is considered congeneric with Phoboscincus, and Dimeropus may not be used while it is considered congeneric with Larutia. Both names remain available for use if Phoboscincus and Larutia are split in the future.

Mesomycterus is a senior subjective synonym of Brachyseps Erens, Miralles, Glaw, Chatrou \& Vences 2017. However, the evidence for the placement of the type species of Mesomycterus in Brachyseps is weak, and it may be possible in the future to separate the two into different genera. Brachyseps has only been in use for four years, too short a time for reversal of precedence to be used.

\section{References}

Adler, G.H., Austin, C.C. \& Dudley, R. (1995) Dispersal and speciation of skinks among archipelagos in the tropical Pacific Ocean. Evolutionary Ecology, 9, 529-541. https://doi.org/10.1007/bf01237834

Barboza du Bocage, J.V. (1872) Diagnoses de quelques espèces nouvelles de Reptiles d'Afrique occidentale. Jornal de Sciencias Mathematicas Physicas e Naturaes, Lisboa, 4 (13), 72-82.

Bauer, A.M. (2013) On the identity of Lacerta punctata Linnaeus 1758, the type species of the genus Euprepis Wagler 1830, and the generic assignment of Afro-Malagasy skinks. African Journal of Herpetology, 52 (1), 1-7. https://doi.org/10.1080/21564574.2003.9635472

Bauer, A.M. \& Sadlier, R.A. (1993) Systematics, biogeography and conservation of the lizards of New Caledonia. Biodiversity Letters, 1, 107-122. https://doi.org/10.2307/2999755

Bauer, A.M. \& Sadlier, R.A. (2000) The herpetofauna of New Caledonia. Society for Study of Amphibians and Reptiles, Ithaca, New York, 310 pp.

Bauer, A.M. \& Vindum, J.V. (1990) A checklist and key to the herpetofauna of New Caledonia, with remarks on biogeography. Proceedings of the California Academy of Science, 47 (2), 17-45.

Bavay, A. (1869) Catalogue des Reptiles de la Nouvelle-Calédonie et description d'espèces nouvelles. Mémoires de la Société Linnéene de Normandie, 15, 1-37. https://doi.org/10.5962/bhl.part.9927

Bell, T. (1833) Characters of two new genera of reptiles. Proceedings of the Zoological Society of London, 1, 98-99.

Beolens, B., Watkins, M. \& Grayson, M. (2011) The Eponym Dictionary of Reptiles. Johns Hopkins University Press, Baltimore, xiii +296 pp. https://doi.org/10.3366/anh.2012.0121

Bleeker, P. (1860) Reptilien van Agam. Natuurkundig Tijdschrift voor Nederlandsch Indie, 20, 325-329.

Böhme,W. (1981) A new lygosomine skink from Thailand (Reptilia: Scincidae) [Larutia osellai]. Bollettino del Museo Civico di Storia Naturale di Verona, 8, 375-382. https://doi.org/10.5962/bhl.title.58522

Boulenger, G.A. (1885a) Catalogue of the Lizards in the British Museum (Natural History). Volume I. Geckonidae, Eublepharidae, Uroplatidae, Pygopodidae, Agamidae. Trustees of the British Museum (Natural History), London, xii + 436 pp., XXXII pls.

Boulenger, G.A (1885b) Catalogue of the Lizards in the British Museum (Natural History). Volume II. Iguanidae, Xenosauridae, Zonuridae, Anguidae, Anniellidae, Helodermatidae, Varanidae, Xantusiidae, Teiidae, Amphisbaenidae. Trustees of the British Museum (Natural History), London, xiii + 497 pp., XXIV pls.

Boulenger, G.A. (1887) Catalogue of the Lizards in the British Museum (Natural History). Vol. III. Lacertidae, Gerrhosauridae, Scincidae, Anelytropidae, Dibamidae, Chamaeleontidae. Trustees of the British Museum (Natural History), London, xii + 575 pp., XL pls.

Brocchi, [P] (1876) Sur un Scincoïdien nouveau appartenant au genre Eumèces. Bulletin de la Société Philomatique de Paris, Series 6, 12, 95-97. https://doi.org/10.5962/bhl.part.18335

Burton, E. (1836) A saurian reptile of the family Scincidae and of the genus Tiliqua, Gray. Proceedings of the Zoological Society of London, 1836, 62.

Caut, S., Holden, M., Jowers, M.J., Boistel, R. \& Ineich, I. (2013) Is Bocourt's Terrific Skink really so terrific? Trophic myth and reality. PLoS One, 8 (10), e78638. 
https://doi.org/10.1371/journal.pone.0078638

Chan, K.O. \& Grismer, L.L. (2021) Integrating spatial, phylogenetic, and threat assessment data from frogs and lizards to identify areas for conservation priorities in Peninsular Malaysia. Global Ecology and Conservation, 28, e01650. https://doi.org/10.1016/j.gecco.2021.e01650

Chan, K.O., Muin, M.A., Anuar, S., Andam, J., Razak, N. \& Aziz, M.A. (2019) First checklist on the amphibians and reptiles of Mount Korbu, the second highest peak in Peninsular Malaysia. Check List, 15 (6), 1055-1069. https://doi.org/10.15560/15.6.1055

Chan-ard, T., Grossmann, W., Gumprecht, A. \& Schulz, K.D. (1999) Amphibians and reptiles of Peninsular Malaysia and Thailand - an illustrated checklist. Bushmaster Publications, Würselen, 240 pp.

Chan-ard, T., Makchai, S. \& Cota, M. (2011a) Jarujinia: a new genus of lygosomines lizard from Central Thailand, with a description of one new species. Thailand Natural History Museum Journal, 5 (1), 17-24.

Chan-ard, T., Cota, M., Makchai, S. \& Lhaotaew, S. (2011b) A new species of Larutia (Squamata: Scincidae) found in Peninsular Thailand. Thailand Natural History Museum Journal, 5 (1), 57-65.

Cope, E.D. (1862) Contributions to Neotropical saurology. Proceedings of the Academy of Natural Sciences of Philadelphia, 14 (5), 176-188.

Cope, E.D. (1869) Observations on reptiles of the Old World. II. Proceedings of the Academy of Natural Sciences of Philadelphia, $20(5), 316-328$.

Cope, E.D. (1892) On degenerate types of scapular and pelvic arches in the Lacertilia. Journal of Morphology, 7 (1), $223-242$. https://doi.org/10.5962/bhl.title.134788

Cope, E.D. (1900) The crocodilians, lizards, and snakes of North America. Report of the U. S. National Museum, 1898, 1551270 , pls $1-36$.

Das, I. \& Lim, K.K.P. (2001) Catalogue of herpetological types in the collection of the Raffles Museum of Biodiversity Research, National University of Singapore. Raffles Bulletin of Zoology, 49 (1), 7-11.

Davidson, J.P. (1997) The Bone Sharp. The life of Edward Drinker Cope. Academy of Natural Sciences of Philadelphia, Philadelphia, Pennsylvania, $\mathrm{x}+237 \mathrm{pp}$.

Daza, J.D., Bauer, A.M., Sand, C., Lilley, I., Wake, T.A. \& Valentin, F. (2015) Reptile remains from Tiga (Tokanod), Loyalty Islands, New Caledonia. Pacific Science, 69 (4), 531-557. https://doi.org/10.2984/69.4.8

Duméril, A.M.C. \& Bibron, G. (1839) Erpétologie Générale ou Histoire Naturelle complète des Reptiles. Tome Cinquième, contenant l'histoire de quatre-vingt-trois genres et de deux cent sept espèces de trois dernières Familles de l'Ordre des Sauriens, savoir: Les Lacertiens, Les Chalcidiens et les Scincoïdiens. Librairie Encyclopédique de Roret, Paris, viii + 854 $+[1] \mathrm{pp}$. https://doi.org/10.5962/bhl.title.45973

Duméril, [A.M.]C. \& Duméril, A. (1851) Muséum d'Histoire Naturelle de Paris. Catalogue Méthodique de la Collection des Reptiles. Gide et Baudry, Paris, iv + 224 pp.

Dunn, E.R. \& Dunn, M.T. (1940) Generic names proposed in herpetology by E. D. Cope. Copeia, 1940 (2), 69-76. https://doi.org/10.2307/1439044

Erens, J., Miralles, A., Glaw, F., Chatrou, L.W. \& Vences, M. (2017) Extended molecular phylogenetics and revised systematics of Malagasy scincine lizards. Molecular Phylogenetics and Evolution, 107, 466-472. https://doi.org/10.1016/j.ympev.2016.12.008

Fischer, J.G. (1882) Herpetologische Bemerkungen. II. Neue Eidechen aus Australien und Polynesien. Archiv für Naturgeschichte, 48 (1), 286-302, pls. xvi-Xvii.

Fitzinger, L.I. (1826) Neue Classification der Reptilien nach ihren naturlichen verwandtschaften. Nebst einer verwandtschaftstabel und einem verzeichnisse der reptilien-sammlung des K. K. Zoologischen Museum's zu Wien. J.G. Heubner, Wien, [vi] +66 pp., 1 pl. https://doi.org/10.5962/bhl.title.4683

Fitzinger, L. (1843) Systema Reptilium. Fasciculus Primus. Amblyglossae. Braumüller et Seidel, Vindobonae, $106+$ vi + [3] pp.

Freitas, E.S., Datta-Roy, A., Karanth, P., Grismer, L.L. \& Siler, C.D. (2019) Multilocus phylogeny and a new classification for African, Asian and Indian supple and writhing skinks (Scincidae: Lygosominae). Zoological Journal of the Linnean Society, 186 (4), 1067-1096. https://doi.org/10.1093/zoolinnean/zlz001

Geneva, A.J., Bauer, A.M., Sadlier, R.A. \& Jackman, T.R. (2013) Terrestrial herpetofauna of Île des Pins, New Caledonia, with an emphasis on its surrounding islands. Pacific Science, 67 (4), 571-593. https://doi.org/10.2984/67.4.8

Goldberg, S.R., Bursey, C.R. \& Grismer, L.L. (2015) Larutia trifasciata (Three-banded Larut Skink). Endo-parasite. Herpetological Review, 46 (2), 259.

Goldberg, S., Bursey, C.R. \& Grismer, L.L. (2019a) Endoparasiten des Larutskinks Larutia larutensis (Squamata: Scincidae) von der Malaiischen Halbinsel. Sauria, 41 (3), 61-62.

Goldberg, S.R., Bursey, C.R. \& Grismer, L.L. (2019b) Endoparasites in the Three-banded Larut Skink, Larutia trifasciata (Squamata: Scincidae) from Peninsular Malaysia. Texas Journal of Science, 71 (1): Note 4. 
https://doi.org/10.32011/txjsci_71_1_note4

Grandidier, A. (1872) Descriptions de quelques Reptiles nouveaux découverts á Madagascar en 1870. Annales des Sciences Naturelles, Zoologie et Paléontologie, 15 (5), 6-11.

Gray, J.E. (1831) A synopsis of the species of the Class Reptilia. In: Griffith, E. \& Pidgeon, E. The Animal Kingdom arranged in conformity with its organization, by the Baron Cuvier, member of the Institute of France, \&c. \&c. \&c. with additional description of all the species hitherto named, and of many not before noticed. Volume 9. The Class Reptilia arranged by the Baron Cuvier, with specific descriptions. Whittaker, Treacher, and Co., London, pp. 1-110. https://doi.org/10.1017/cbo9781139226950.003

Gray, J.E. (1845) Catalogue of the specimens of lizards in the collection of the British Museum. Edward Newman, London, xxviii +289 pp.

Gray, J.E. (1864) Notice of a new variety of Rhodona punctata from the Swan River. Proceedings of the Zoological Society of London, 1864, 296.

Greer, A.E. (1974) The generic relationships of the scincid lizard genus Leiolopisma and its relatives. Australian Journal of Zoology, Supplementary Series, 31, 1-67. https://doi.org/10.1071/ajzs031

Greer, A.E. (1997) Leptoseps: a new genus of scincid lizards from Southeast Asia. Journal of Herpetology, 31 (3), $393-398$. https://doi.org/10.2307/1565668

Greer, A.E. (2001) Distribution of maximum snout-vent length among species of scincid lizards. Journal of Herpetology, 35 (3), 383-395. https://doi.org/10.2307/1565956

Greer, A.E. (2002) The loss of the external ear opening in scincid lizards. Journal of Herpetology, 36 (4), 544-555. https://doi.org/10.1670/0022-1511(2002)036[0544:tlotee]2.0.co;2

Greer, A.E. \& Chong, J. (2007) Number of maxillary teeth in scincid lizards: lineage characteristics and ecological implications. Journal of Herpetology, 41 (1), 94-101. https://doi.org/10.1670/0022-1511(2007)41[94:nomtis]2.0.co;2

Greer, A., David, P. \& Teynié, A. (2006) The Southeast Asian scincid lizard Siaphos tridigitus Bourret, 1939 (Reptilia, Scincidae): a second specimen. Zoosystema, 28 (3), 785-790.

Grismer, J.L., Leong, T.M. \& Yaakob, N.S. (2003) Two new Southeast Asian skinks of the genus Larutia and intrageneric phylogenetic relationships. Herpetologica, 59 (4), 552-564. https://doi.org/10.1655/02-56

Grismer, J.L., Grismer, L.L., Das, I., Yaakob, N.S., Boo Liat, L., Leong, T.M., Youmans, T.M. \& Kaiser, H. (2004) Species diversity and checklist of the herpetofauna of Pulau Tioman, Peninsular Malaysia, with a preliminary overview of habitat utilization. Asiatic Herpetological Research, 10, 247-279.

Grismer, L.L. (2011) Lizards of Peninsular Malaysia, Singapore and their adjacent archipelagos. Edition Chimaira, Frankfurt, $728 \mathrm{pp}$.

Grismer, L.L. \& Quah, E.S.H. (2019) An updated and annotated checklist of the lizards of Peninsular Malaysia, Singapore, and their adjacent archipelagos. Zootaxa, 4545 (2), 230-248. https://doi.org/10.11646/zootaxa.4545.2.4

Grismer, L.L., Onn, C.K., Grismer, J.L., Wood, P.L. \& Norhayati, A. (2010) A checklist of the herpetofauna of the Banjaran Bintang, Peninsular Malaysia. Russian Journal of Herpetology, 17 (2), 147-160.

Grismer, L.L., Quah, E.S.H., C.D., Chan, K.O., Wood, P.L., Grismer, J.L., Sah, S.A.M. \& Ahmad, N. (2011) Peninsular Malaysia's first limbless lizard: a new species of skink of the genus Larutia (Bohme) from Pulau Pinang with a phylogeny of the genus. Zootaxa, 2799 (1), 29-40. https://doi.org/10.11646/zootaxa.2799.1.3

Günther, A. (1864) Report on a collection of reptiles and fishes made by Dr. Kirk in the Zambesi and Nyassa regions. Proceedings of the Zoological Society of London, 1864 (2), 303-314.

Günther, A. (1867) Additions to the knowledge of Australian reptiles and fishes. Annals and Magazine of Natural History, Series 3, 20 (115), 45-57. https://doi.org/10.1080/00222936708562716

Günther, A. (1873) Notes on some reptiles and batrachians obtained by Dr. Bernhard Meyer in Celebes and the Philippine Islands. Proceedings of the Zoological Society of London, 1873 (1), 165-172.

Günther, A. (1876) Descriptions of new species of reptiles from Australia collected by Hr. Dämel for the Godeffroy Museum. Journal des Museum Godeffroy, 5 (12), 45-47.

Günther, A. (1877) Descriptions of some new species of reptiles from Madagascar. Annals and Magazine of Natural History, Series 4, 19 (112), 313-317. https://doi.org/10.1080/00222937708682150

Günther, A. (1880) Description of new species of reptiles from eastern Africa. Annals and Magazine of Natural History, Series $5,6(33), 234-238$. https://doi.org/10.1080/00222938009458928

Günther, A. (1882) Ninth contribution to the knowledge of the fauna of Madagascar. Annals and Magazine of Natural History, Series 5, 9 (52), 262-266. 
https://doi.org/10.1080/00222938209459038

Hardwicke, [T.] \& Gray, J.E. (1827) A synopsis of the species of saurian reptiles, collected in India by Major-General Hardwicke. Zoological Journal, 3 (10), 213-229.

Hedges, S.B. (2014) The high-level classification of skinks (Reptilia, Squamata, Scincomorpha). Zootaxa, 3765 (4), $317-338$. https://doi.org/10.11646/zootaxa.3765.4.2

Hedges, S.B. \& Conn, C.E. (2012) A new skink fauna from Caribbean islands (Squamata, Mabuyidae, Mabuyinae). Zootaxa, $3288(1), 1-244$.

https://doi.org/10.11646/zootaxa.3288.1.1

Ibuki, F., Hikida, T., Hossman, M.Y. \& Nishikawa, K. (2019) A new species of the genus Larutia (Squamata: Scincidae) from Gunung Penrissen, Sarawak, Borneo. Zootaxa, 4661 (3), 522-532. https://doi.org/10.11646/zootaxa.4661.3.6

Ineich, I. (2006) Bocourt's Terrific Skink of New Caledonia is not extinct! Oryx, 40 (2), 136.

Ineich, I. (2009) Bocourt's Terrific Skink, Phoboscincus bocourti Brocchi, 1876 (Squamata, Scincidae, Lygosominae). In: Grandcolas, P. (Ed.), Zoologia Neocaledonica 7. Biodiversity studies in New Caledonia. Mémoires du Muséum national d'Histoire naturelle, 198, pp. 149-174.

Ineich, I., Sadlier, R.A., Bauer, A.M., Jackman, T.R. \& Smith, S.A. (2014) Bocourt's Terrific Skink, Phoboscincus bocourti (Brocchi, 1876), and the monophyly of the genus Phoboscincus Greer, 1974 (Reptilia: Scincidae). Mémoires du Muséum national d'Histoire naturelle, 206, 69-78.

Lang, M. \& Böhme, W. (1990) Description and phylogenetic position of a new species of Isopachys from central Thailand and southern Burma/Myanmar (Squamata, Scincidae). Bulletin de l'Institut Royal des Sciences Naturelles de Belgique, Biologie, 60, 231-240.

Langner, C. \& Sound, P. (2016) First data on the dietary spectrum and activity of the New Caledonian Giant Skink, Phoboscincus garnieri (Bavay, 1869). Sauria, 38 (3), 57-59.

Laurenti, J.N. (1768) Specimen medicum, exhibens synopsin reptilium emendatam cum experimentis circa venena et antidota reptilium austriacorum. Joan. Thom. Nob. De Trattnern, Viennae, 214 pp., V pls. https://doi.org/10.5962/bhl.title.5108

Lichtenstein, H. (1823) Verzeichniss der Doubletten des zoologischen Museums der Königl. Universität zu Berlin nebst Beschreibung vieler bisher unbekannter Arten von Säugethieren, Vögeln, Amphibien und Fischen. T. Trautwein, Berlin, x +118 pp., 1 pl. https://doi.org/10.5962/bhl.title.40281

Manthey, U. \& Grossmann, W. (1997) Amphibien \& Reptilien Südostasiens. Natur und Tier Verlag, Münster, 512 pp.

Mausfeld, P., Schmitz, A., Böhme, W., Misof, B., Vrcibradic, D. \& Rocha, C.F.D. (2002) Phylogenetic affinities of Mabuya atlantica Schmidt, 1945, endemic to the Atlantic Ocean archipelago of Fernando de Noronha (Brazil): necessity of partitioning the genus Mabuya Fitzinger, 1826 (Scincidae: Lygosominae). Zoologischer Anzeiger, 241 (3), $281-293$. https://doi.org/10.1078/0044-5231-00081

Meiri, S. (2008) Evolution and ecology of lizard body sizes. Global Ecology and Biogeography, 17, 724-734. https://doi.org/10.1111/j.1466-8238.2008.00414.x

Mittermeier, R.A., Werner, T.B. \& Lees, A. (2009) New Caledonia - a conservation imperative for an ancient land. Oryx, 30 (2), 104-112. https://doi.org/10.1017/s0030605300021487

Mittleman, M.B. (1952) A generic synopsis of the lizards of the subfamily Lygosominae. Smithsonian Miscellaneous Collections, $117(17), 1-35$.

Neave, S.A. (1939-1940) Nomenclator Zoologicus. A list of the names of genera and subgenera in Zoology from the tenth edition of Linnaeus 1758 to the end of 1935. 4 Vols. Zoological Society of London, London, xi $+957+1025+1065+758$ pp. https://doi.org/10.2307/1439031

Norhayati, A., Farah, A.D., Chan, K.O., Daicus, B. \& Muin, M.A. (2011) An update of herpetofaunal records from Bukit Fraser, Pahang, Peninsular Malaysia. Malaysian Applied Biology, 40, 9-17.

O'Shaughnessy, A.W.E. (1879) Description of new species of lizards in the collection of the British Museum. Annals and Magazine of Natural History, Series 5, 4 (22), 295-303. https://doi.org/10.1080/00222937908679832

O'Shea, M. (2021) Lizards of the World: A Guide to Every Family. Ivy Press, London, 239 pp.

Peters, W. (1867) Herpetologische Notizen. Monatsberichte der königlich Akademie der Wissenschaften zu Berlin, 1867 (January), 13-37.

Peters, W. (1871) Über neue Reptilien aus Ostafrica und Sarawak (Borneo), vorzüglich aus der Sammlung des Hrn. Marquis J. Doria zu Genua. Monatsberichte der königlich Akademie der Wissenschaften zu Berlin, 1871(November), 566-581. https://doi.org/10.1515/9783112417867-025

Peters, W. (1874) Über neue Saurier (Spaeriodactylus, Anolis, Phrynosoma, Tropidolepisma, Lygosoma, Ophioscincus) aus Centralamerica, Mexico und Australien. Monatsberichte der königlich Akademie der Wissenschaften zu Berlin, 1873 (November), 738-747.

Pyron, R.A., Burbrink, F.T. \& Wiens, J.J. (2013) A phylogeny and revised classification of Squamata, including 4161 species of 
lizards and snakes. BMC Evolutionary Biology, 13, 93.

https://doi.org/10.1186/1471-2148-13-93

Quah, E.S.H. \& Sah, S.A.M. (2018) Herpetofauna of the northern corridor: a review of recent herpetological discoveries around the Malaysian-Thai border regions. Journal of Wildlife and Parks, 33, 15-29.

Rodda, G.H. (2020) Lizards of the World. Natural History and Taxon Accounts. Johns Hopkins University Press, Baltimore, $832 \mathrm{pp}$.

Rodriguez, Z.B., Perkins, S.L. \& Austin, C.C. (2018) Multiple origins of green blood in New Guinea lizards. Science Advances, 4, eaao5017. https://doi.org/10.1126/sciadv.aao5017

Sadlier, R.A. (1987) ["1986"] A review of the scincid lizards of New Caledonia. Records of the Australian Museum, 39 (1), $1-66$. https://doi.org/10.3853/j.0067-1975.39.1987.164

Sadlier, R.A. \& Bauer, A.M. (1997a) The terrestrial herpetofauna of the Loyalty Islands. Pacific Science, 51 (1), $76-90$.

Sadlier, R.A. \& Bauer, A.M. (1997b) A new genus and species of lizard (Reptilia: Scincidae) from New Caledonia, Southwest Pacific. Pacific Science, 51 (1), 91-96. https://doi.org/10.2984/1534-6188(2009)63[123:anlsos]2.0.co;2

Sadlier, R.A., Debar, L., Chavis, M., Bauer, A.M., Jourdan, H. \& Jackman, T.R. (2019) Epibator insularis, a new species of scincid lizard from l'Île Walpole, New Caledonia. Pacific Science, 73 (1), 143-161. https://doi.org/10.2984/73.1.7

Shea, G.M. (2017) Generic allocation of the enigmatic scincid lizard Lygosoma inconspicuum F. Müller, 1895 (Squamata: Scincidae) from Sulawesi. In: Telnov, D., Barclay, M.V.L. \& Pauwels, O.S.G. (Eds.), Biodiversity, Biogeography and Nature Conservation in Wallacea and New Guinea. Vol. 3. Entomological Society of Latvia, Riga, pp. 27-33, pls. 2-3. https://doi.org/10.5962/bhl.title.150137

Smith, S.A., Sadlier, R.A., Bauer, A.M., Austin, C.C. \& Jackman, T. (2007) Molecular phylogeny of the scincid lizards of New Caledonia and adjacent areas: evidence for a single origin of the endemic skinks of Tasmantis. Molecular Phylogenetics and Evolution, 43 (3), 1151-1166. https://doi.org/10.1016/j.ympev.2007.02.007

Teynié, A., David, P. \& Ohler, A. (2010) Note on a collection of amphibians and reptiles from Western Sumatra (Indonesia), with the description of a new species of the genus Bufo. Zootaxa, 2416 (1), 1-43. https://doi.org/10.11646/zootaxa.2416.1.1

Thibault, M., Brescia, F., Jourdan, H. \& Vidal, E. (2017) Invasive rodents, an overlooked threat for skinks in a tropical island hotspot of biodiversity. New Zealand Journal of Ecology, 41 (1), 74-83. https://doi.org/10.20417/nzjecol.41.9

Wagner, P., Bohme, W., Pauwels, O.S.G. \& Schmitz, A. (2009) A review of the African red-flanked skinks of the Lygosoma fernandi (Burton, 1836) species group (Squamata: Scincidae) and the role of climate change in their speciation. Zootaxa, $2050(1), 1-30$. https://doi.org/10.11646/zootaxa.2050.1.1

Weinell, J.L., Branch, W.R., Colston, T.J., Jackman, T.R., Kuhn, A., Conradie, W. \& Bauer, A.M. (2019) A species-level phylogeny of Trachylepis (Scincidae: Mabuyinae) provides insight into their reproductive mode evolution. Molecular Phylogenetics \& Evolution, 136, 183-195. https://doi.org/10.1016/j.ympev.2019.04.002 